\title{
Safety and Efficacy of Meglitinides in Combination with GLP-1 Analogues- A Case Series
}

\author{
Begho Obale ${ }^{1}$ and Moulinath Banerjee ${ }^{1,2 *}$ \\ ${ }^{1}$ University Hospitals of Morecambe Bay NHS Foundation Trust, UK \\ ${ }^{2}$ Diabetes \& Endocrine Research group, Manchester University, UK
}

Submission: February 27, 2017; Published: March 20, 2017

*Corresponding author: Moulinath Banerjee, MBBS, MD, PhD, FRCP, Bolton NHS Foundation Trust, Manchester University, Minerva Road, Bolton UK, BL4 0JR, England, UK, Tel: 0044-0-1204-390583; Fax: 0044-0-1204-390552; Email: endobanerjee@gmail.com

\begin{abstract}
Combination of meglitinides and GLP1 analogues use has not been reported in clinical trials. Here we report for the first time, a series of 5 cases of successful usage of these two drug classes, in patients who developed hypoglycaemia in combination with Gliclazide and GLP1 analogues in relation to abolition of hypoglycaemia, weight loss and improvement in glycaemic control.
\end{abstract}

\section{Introduction}

Sulphonylureas (SU) and GLP-1 analogues (GLP1a) are commonly used therapeutic modalities for patients with Type 2 diabetes. Sulphonylureas and Meglitinides, both work as insulin secretagogues, by binding to the SUR subunits of the K+ATP channels of the beta-cells of the pancreatic islets [1] and short duration of action of the Meglitinides contributes to their lower risk for hypoglycaemia when compared to SUs [2,3]. GLP1a are known to induce glucose augmented insulin release and have a low incidence of hypoglycaemia-seen mostly when used in combination with a SU [4]. There have been no reported studies to date, reporting usage of the combination of Meglitinides and GLP1a with or without metformin therapy.

\section{Method and Patients}

Between November 2011 and March 2012, 5 patients with Type 2 Diabetes had reported recurrent pre-lunch hypoglycaemia at our Secondary Care Diabetes clinic at Westmoreland General Hospital, Kendal. All of them were on treatment with a SU (Gliclazide $80-160 \mathrm{mg} /$ day) and a GLP1a (Exenatide 10mcg BD/ Liraglutide 1.2mg OD) along with Metformin (1.7-2.55g/day). The choice of the GLP1a was decided prior to the study period, depending on whether patients agreed to once or twice daily injections. Gliclazide was replaced by Nateglinide/Repaglinide and their dose titrated with informed consent of the patient. Generic Nateglinide was preferred after the first patient was started on Repaglinide, because of cost-effectiveness. They all continued with their GLP1a and Metformin as before. All treatment and dose titration decisions were undertaken by either of the two authors. After treatment for a mean duration of $35.0+23.1$ weeks with this new combination therapy, patients were evaluated for improvement in glycaemia, adiposity, any adverse reactions either reported or detected by routine biochemical investigations.

\section{Results}

Table 1: Characteristics of patients.

\begin{tabular}{|c|c|c|c|c|c|c|}
\hline $\begin{array}{c}\text { Case } \\
\text { No. }\end{array}$ & $\begin{array}{c}\text { Gen- } \\
\text { der }\end{array}$ & Age & $\begin{array}{c}\text { Dura- } \\
\text { tion of } \\
\text { Diabe- } \\
\text { tes }\end{array}$ & $\begin{array}{c}\text { Weeks } \\
\text { of } \\
\text { Thera- } \\
\text { py }\end{array}$ & $\begin{array}{c}\text { Megli- } \\
\text { tinides }\end{array}$ & GLP-1a \\
\hline 1 & M & 55.6 & 4.2 & 74.6 & Nateglinide & Liraglutide \\
\hline 2 & F & 68.9 & 5.7 & 24.1 & Nateglinide & Exenatide \\
\hline 3 & F & 76.7 & 8.1 & 15.6 & Repaglinide & Exenatide \\
\hline 5 & M & 61.4 & 4.8 & 26 & Nateglinide & Liraglutide \\
\hline 5 & F & 57.8 & 5.6 & 34.7 & Nateglinide & Exenatide \\
\hline
\end{tabular}

These 5 patients ( 3 women) had a mean age of $64.1 \pm 8.7$ years and their mean duration of diabetes was $5.7 \pm 1.5$ years (Table 1). There were 4 patients on Nateglinide and 3 patients on Exenatide. Following change to a meglitinide, none of the patients reported any hypoglycaemia. There was a mean reduction in BMI by $0.92(33.3$ vs. 32.4$) \mathrm{kg} / \mathrm{m}^{2}$. There was a reduction in $\mathrm{HbA} 1 \mathrm{c}$ by $0.9 \%$ (10.04 vs. 9.12 ) or 10.0 (86 vs. 76$) \mathrm{mmol} / \mathrm{mol}$ over the treatment period (Figure 1). There were neither any adverse reactions reported nor detected by biochemical investigations in any of these patients. 


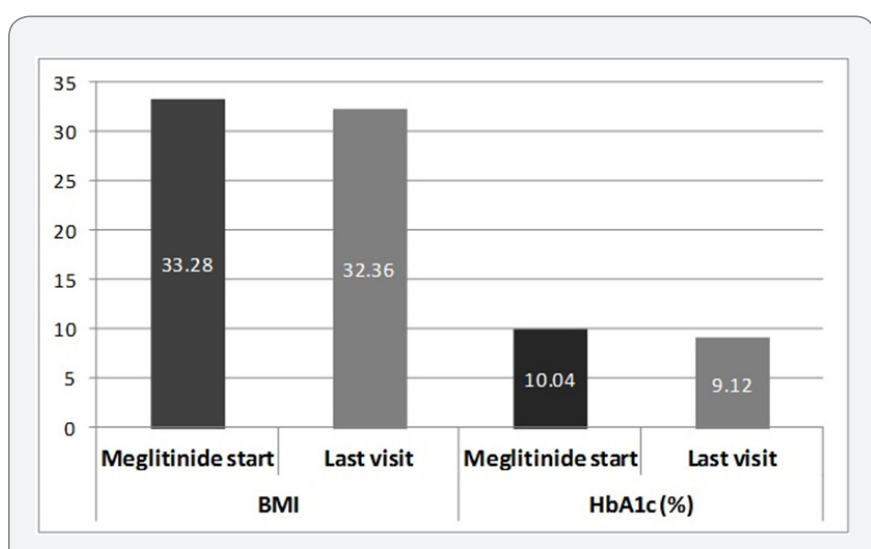

Figure 1: Changes in $\mathrm{HbA1c}$ and BMI during the study period.

\section{Discussion}

The primary aim (reducing hypoglycaemia) of using a Meglitinide was successful in all patients. This can be attributed to

A. Glucose dependent insulin secretagogic action of GLP1a [4]

B. Shorter duration of action of Meglitinides [3] when compared to Gliclazide and

C. Extremely low risk of hypoglycaemia with metformin [5]

The reduction in BMI observed, was due to the reduction in need for treating hypoglycaemia, the effect of the combination of metformin and GLP1a and reduction in the need of glucose \& carbohydrate intake to treat or prevent hypoglycaemia. Meglitinides have been reported to induce weight gain when compared to metformin7which was similar to SUs [5], but the effect we saw was much less than reported. The fall in HbA1c was due to more stable glycaemic profiles as well reduction of hypoglycaemia. Further HbA1c reduction would probably be observed with further reduction in weight in future, if they continue with the current treatment regimen.

It is well known that reduction in hypoglycaemia and weight loss with pharmacological therapies of patients with Type 2
Diabetes improves their treatment satisfaction [6], which can have positive impact on compliance with their treatment [7].

\section{Conclusion}

The combination of a meglitinide and a GLP1a provides an avenue of reduction in hypoglycaemia and weight in patients with Type 2 Diabetes who have significant hypoglycaemia with SUs. This group of drugs, which are not used very commonly, can therefore be beneficial in this select group of patients. Further data regarding the safety and efficacy of such a combination should be validated by a randomised controlled trial over a longer treatment period $[8,9]$.

\section{References}

1. Gribble FM, Reimann F (2003) Differential selectivity of insulin secretagogues: mechanisms, clinical implications, and drug interactions. J Diabetes Complications 17(2): 11-15.

2. Holstein A, Egberts EH (2003) Risk of hypoglycaemia with oral antidiabetic agents in patients with Type 2 diabetes. Experimental and clinical endocrinology \& diabetes 111(7): 405-414.

3. Dornhorst A (2001) Insulinotropic meglitinide analogues. The Lancet 358(9294): 1709-1716.

4. Amori RE, Lau J, Pittas AG (2007) Efficacy and safety of incretin therapy in type 2 diabetes: systematic review and meta-analysis. JAMA 298(2): 194-206.

5. Bolen S, Feldman L, Vassy J, Wilson L, Yeh HC, et al. (2007) Systematic review: comparative effectiveness and safety of oral medications for type 2 diabetes mellitus. Ann Intern Med 147(6): 386-399.

6. Marrett E, Stargardt T, Mavros P, Alexander CM (2009) Patient-reported outcomes in a survey of patients treated with oral antihyperglycaemic medications: associations with hypoglycaemia and weight gain. Diabetes Obes Metab 11(12): 1138-1144.

7. Albano S, Orbiter Study Group (2004) Assessment of quality of treatment in insulin-treated patients with diabetes using a pre-filled insulin pen. The ORBITER Study Group Acta Biomed 75(1): 34-39.

8. US National Library of Medicine (2013) NATEGLINIDE tablet. National Institutes of Health, Health \& Human Services, USA.

9. Black C, Donnelly P, McIntyre L, Royle PL, Shepherd JP, et al. (2007) Meglitinide analogues for type 2 diabetes mellitus. Cochrane Database Syst Rev 2: CD004654.

\section{Your next submission with Juniper Publishers} will reach you the below assets

- Quality Editorial service

- Swift Peer Review

- Reprints availability

- E-prints Service

- Manuscript Podcast for convenient understanding

- Global attainment for your research

- Manuscript accessibility in different formats

( Pdf, E-pub, Full Text, Audio)

- Unceasing customer service

Track the below URL for one-step submission https://juniperpublishers.com/online-submission.php 